\title{
Insecticidal and biological effects of three plant extracts tested against the dengue vector, Stegomyia agyptii (Diptera: Culicidae)
}

\author{
R. Kokila, A. Nareshkumar, K. Meenambigai, B. Nataraj, S. Abdulla, R. Shanmugapriya, \\ K. Chandhirasekar, A.T. Manikandan
}

Department of Zoology, School of Life Sciences, Periyar University, Salem, Tamil Nadu, India

\begin{abstract}
Development of resistant in vectors especially vector mosquitoes are becoming a challenge for the scientific community for management and control mosquito population. Vector mosquitoes are likely to withstand toxicity and develop resistant mechanism to single active compound hence, combining medicinal plants with rich active compounds stops resistant development and proliferation of mosquitoes. In this study we put effort to evaluate the effect of methanol extract of Tagetes patula, Clerodentron phillomedis, and Catharanthus roseus in individual and in combination against the dengue vector, Stegomyia agyptii. Lethal concentrations $\left(\mathrm{LC}_{50}\right.$ and $\mathrm{LC}_{90}$ ) were calculated to find out the effect of the test plants in individual and in combination. T. patula extract showed vaguely higher mortality rate when compared to $C$. phillomedis, and $C$. roseus but there was no significant variation among the three test plants. The median LC of combined treatment showed a significant difference between the combined $\left(2.25 \mu \mathrm{g} / \mathrm{mL} / 3^{\text {rd }}\right.$ instar) and individual treatment $\left(6.41 \mu \mathrm{g} / \mathrm{mL} / 3^{\text {rd }}\right.$ instar for $T$. patula, $6.85 \mu \mathrm{g} / \mathrm{mL} / 3^{\text {rd }}$ instar for $C$. phillomedis and $6.59 \mu \mathrm{g} / \mathrm{mL} / 3^{\text {rd }}$ instar for $C$. roseus). The combined efficacy of three test plants was also effective
\end{abstract}

Correspondence: Arjunan Nareshkumar, Department of Zoology, School of Life Sciences, Periyar University, Salem - 636011, Tamil Nadu, India.

Tel.: +91.427.2345766 - Ext. 328 .

E-mail: naresh@periyaruniversity.ac.in

Key words: Tagetes patula; Clerodentron phillomedies; Catharanthu roseus; vectors; Stegomyia agyptii; larvicide, pupicide.

Acknowledgements: the authors are extremely indebted to convey their bouquet of thanks to the Department of Science and Technology, Science \& Engineering Research Board (SERB), New Delhi-110070, India for providing Young Scientist Award and funds (Award Registration No. SERB/LS1074/2013) to run the project successfully.

Received for publication: 12 September 2015.

Revision received: 24 November 2015.

Accepted for publication: 25 November 2015.

(C) Copyright R. Kokila et al., 2016

Licensee PAGEPress, Italy

Journal of Entomological and Acarological Research 2016; 48:5515

doi:10.4081/jear.2016.5515

This article is distributed under the terms of the Creative Commons Attribution Noncommercial License (by-nc 4.0) which permits any noncommercial use, distribution, and reproduction in any medium, provided the original author(s) and source are credited. in controlling vector mosquitoes at fields with different agro-climatic conditions. The study proves that the combination of T. patula, $C$. phillomedis, and $C$. roseus is effective in different field conditions at lower concentrations.

\section{Introduction}

Mosquitoes are medically and economically significant groups of insects among dipterans. They transmit disease-causing pathogens that can have devastating impacts on humans (Sivapriyajothi et al., 2014). Most important vector borne diseases such as malaria, lymphatic filariasis, Japanese encephalitis, dengue and chikungunya as well as yellow fever and other forms of encephalitis are transmitted by different mosquito species of Anopheles, Aedes and Culex genera (Jayapriya \& Gricilda, 2015). Mosquito-borne infections have an economic impact, including death in countries with tropical and subtropical climates; however, no part of the world is free from vector-borne diseases (Amerasan et al., 2015). Dengue is an important mosquito transmitted viral disease, which is prevalent in more than 100 endemic countries (Marques \& Kaplan, 2015). An estimated 2.5 billion people live in areas under threat of the disease. Nearly half a million cases of infections progress to more severe forms, such as hemorrhagic dengue fever leading to death (Guzman et al., 2010). The disease is transmitted by Stegomyia (=Aedes) mosquitoes and constitutes a serious public health threat worldwide (WHO, 2009; De la MoraCovarrubias et al., 2010; Fonseca-González et al., 2011; Khan et al., 2011; Brathwaite Dick et al., 2012).

In tropical countries like India, outbreak of dengue result in thousands of hospital admissions, human suffering and massive economic losses however, early recognition and prompt treatment can lower the risk of developing this severe disease (Epelboin et al., 2013). However, there are no available vaccines or effective antiviral agents against the virus. Hence in such case, mosquito control, assumes global importance (Nareshkumar et al., 2015). Synthetic and chemical insecticides resulted in environmental hazards and also in development of physiological resistance among vector mosquito species. Secondary metabolites of plants are considered to be a potential alternative approach for control insect pests as they are environmentally safe, target specific and biodegradable (Jayapriya \& Gricilda, 2015).

Plant could be an alternative source for mosquito larvicides because they constitute a potential source of bioactive chemicals and generally free from harmful effects. Use of these botanical derivatives in mosquito control instead of syhthetic insecticides could reduce the cost and environmental pollution. Further analysis is required to isolate the active and its mode of action in inhibiting the developmental of Stegomyia aegypti larvae (Rajasekaran \& Duraikannan, 2012).

The active metabolites of many plants were found to exhibit insecti- 
cidal activity against mosquitoes and other vectors and also nontoxic to human and other non-target organisms. They are promising candidates to replace conventional insecticides to which insects are becoming more resistant (Cantrell et al., 2012; Vontas et al., 2012; Nareshkumar et al., 2013; Reegan et al., 2014; Miresmailli \& Isman, 2014).

Most of the medicinal plants around our environment are found to possess various properties. The utilization of these resources will definitely contribute to control a wide range of pests (Vadeyar et al., 2010). Tagetes patula Linn., (family Asteraceae), is used in folk medicine as an insect repellent, antiseptic, diuretic, blood purifier and also for cancer treatment (Vanessa et al., 2015; Kashif et al., 2015). The chemical constituents of Tagetes patula are $\beta$-karyophyllene, terpenes, hydrocarbons, alcohols, ethers, aldehydes, ketones, esters, carotenoids, flavonoids and thiophenes (Camarillo et al., 2007; Prakash et al., 2012).

Clerodendrum phlomidis (family Lamiaceae) is an important medicinal plant contains secondary metabolites like tannins, alkaloids, polyphenols, terpenoids, and essential oils which have a wide range medicinal properties used in treatment of inflammation diabetes, nervous disorders, asthma, rheumatism, digestive disorders, urinary disorders and also has insecticidal activity (Ahmad, 2007; Lakshmi \& Viji Stella Bai, 2015). Catharanthus roseus (L.) (family Apocynaceae) is another medicinal plant constitutes two important secondary metabolites viz. vincristine and vinblastine, the invaluable antitumor terpenoid indole alkaloids (Nejat et al., 2015). It also has other medicinal properties, such as antibacterial, antifungal and antiviral activities (Jaleel et al., 2007).

Enormous plant species viz. Hippocratea excelsa, Hippocratea celastroides, Argemone mexicana, Tagetes lucida, Pseudosmodingium perniciosum (Ruiz-Guerrero et al., 2015), T. patula (Munhoz et al., 2014), C. phlomidis (Kashte et al., 2015), C. roseus (Panneerselvam et al., 2013), Blepharis maderaspatensis, Elaeagnus indica, Maesa indica, Phyllanthus wightianus, Memecylon edule (Shivakumar et al., 2013), etc. have been used to control different mosquito species in recent years.

The present investigation was carried out to examine the larval toxicity, pupal toxicity and adult toxicity of methanol extracts of T. patula (French marigold or Honey comb), C. phillomedis (Urni, Arna or Aarni), and C. roseus (Madagascar periwinkle or rosy periwinkle) against dengue vector, St. aegypti and their impact upon adult longevity and fecundity. The results of the present study may lead to the development of target specific and environmentally safer insecticidal products.

\section{Materials and methods}

\section{Tested mosquitoes}

All tests were carried out against the dengue vector, Stegomyia (St.) aegypti (L.).

\section{Colony establishment and maintenance}

The eggs of St. aegypti, were collected using oviposition traps placed in shaded areas at a height of less than $1.2 \mathrm{~m}$. Traps were filled with water plus a few dried leaves placed at the bottom of the container, with a muslin strip placed vertically inside the container and half-submerged in the water. The eggs were then brought to the laboratory and transferred to $18 \times 13 \times 4 \mathrm{~cm}$ size enamel trays containing $500 \mathrm{~mL}$ water and kept for larval hatching. The St. aegypti larval culture was maintained in our laboratory at $27+2^{\circ} \mathrm{C}$. The larvae were fed with dog biscuits and yeast at $3: 1$ ratio. The feeding was continued till the larvae transformed into the pupae. Water was changed alternate days. The breeding medium was regularly checked and dead larvae were removed at sight.

The pupae were collected from culture trays and were transferred to glass beakers containing $500 \mathrm{~mL}$ of water with help of a sucker. The pupae containing glass beaker were kept in $(90 \mathrm{~cm} \mathrm{~L} \times 90 \mathrm{~cm} \mathrm{H} \times 90 \mathrm{~cm}$ W) $\mathrm{cm}$ size mosquito cage for adult emergence. The emerged adults were maintained at $27.2^{\circ} \mathrm{C}, 75-85 \%$ relative humidity, under $14: 10$ light:dark photoperiod cycles. The adults were fed with $10 \%$ sugar solution for a period of three days before they were provided an animal for blood feeding. The adult female mosquitoes were allowed to feed on the blood of rabbit (exposed on the dorsal side) for two days. The males were provided with $10 \%$ glucose solution on cotton wicks. The cotton was kept moist with the solution and changed every day. An egg trap (cup) lined with filter paper containing water was placed in a corner of the egg collection cage.

\section{Collection of plant materials and preparation of extracts}

The leaves of T. patula (Asteraceae), flowers of $C$. phlomidis (Asteraceae), and leaves of $C$. roseus (Apocynaceae) were collected from Salem district, Tamil Nadu, India. The leaves were washed with tap water and dried at room temperature. The dried plant materials were powdered by an electrical blender. From the powder $100 \mathrm{~g}$ of the leaves were extracted with $300 \mathrm{~mL}$ of methanol for $8 \mathrm{~h}$ in a Soxhlet apparatus (Vogel, 1978). The crude plant extracts were evaporated to dryness in rotary vacuum evaporator. The test concentrations $(2 \mathrm{mg} / \mathrm{L}, 4 \mathrm{mg} / \mathrm{L}, 6 \mathrm{mg} / \mathrm{L}, 8 \mathrm{mg} / \mathrm{L}$ and $10 \mathrm{mg} / \mathrm{L}$ ) were prepared using distilled water.

\section{Larval and pupal toxicity test}

F2 larvae/pupae from the wild adult collection were used for the larvicidal/pupicidal activity. Twenty-five of first, second, third, fourth instar larvae and pupae were introduced into the $500 \mathrm{~mL}$ glass beaker containing $300 \mathrm{~mL}$ of de-chlorinated water with the desired concentrations ( $2 \mathrm{mg} / \mathrm{L}, 4 \mathrm{mg} / \mathrm{L}, 6 \mathrm{mg} / \mathrm{L}, 8 \mathrm{mg} / \mathrm{L}$ and $10 \mathrm{mg} / \mathrm{L}$ ) of plant extracts. Food was provided for the test insects. Five replicates were made for each concentration. The control was setup using de-chlorinated water alone. The test mortalities were corrected by using Abbott's formula (Abbott, 1925).

$$
\text { Corrected mortality }=
$$

Observed mortality in treatment - Observed mortality in control $\times 100$ (1)

$$
100 \text { - Control mortality }
$$

\section{Biological observations}

\section{Mosquito fecundity, longevity and egg hatchability test}

The effect of larval exposure to plant extracts on adult longevity, fecundity and egg hatchability of St. aegypti, was determined by placing 20 male and female mosquitoes of similar size and age emerged from each treatment group [twenty-five fourth instar larvae treated with desired concentrations of plant extracts as individual ( $4 \mathrm{mg} / \mathrm{L}$ and $6 \mathrm{mg} / \mathrm{L})$ and in combination $(0.5 \mathrm{mg} / \mathrm{L}, 1.0 \mathrm{mg} / \mathrm{L}$ and $1.5 \mathrm{mg} / \mathrm{L})]$ and the respective control

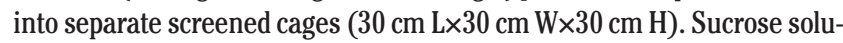
tion was available to adults ad libitum. Commencing $3 \mathrm{~d}$ after blood feeding and until oviposition ceased, eggs or egg rafts were collected daily from plastic bowl ( $12 \mathrm{~cm} \mathrm{H} \times 12 \mathrm{~cm}$ dia) containing $500 \mathrm{ml}$ water that was placed in each cage. The average number of eggs laid by each female in each cage was calculated as the total number of eggs collected in each cage divided by the number of females originally placed in that cage.

To characterize adult longevity, the number of live male and female mosquitoes in each cage was recorded at the same time each day until all mosquitoes had died. This value was divided by the number of male or females originally placed in to the cage to obtain percent survival according to the number of days since emergence.

Hatchability was evaluated using filter papers with the test eggs were cut into portions and placed into a glass cavity block $(50 \times 50 \mathrm{~mm})$ for hatching and counted. The percentage of hatchability was calculated as number of eggs hatched by number of experimented eggs. 
Further the freshly emerged larvae were monitored for its survival rate and adult emergence.

$$
\text { Hatchability }(\%)=\frac{\text { Number of hatched eggs } \times 100}{\text { Number of tested eggs }}
$$

\section{Statistical analysis}

All data were subjected to analysis of variance and the means were separated using Duncan's multiple range test (Alder \& Rossler, 1977). The mean values of larvae, and pupae mortality were subjected to probit analysis (Finney, 1971) for calculating lethal concentrations at 50\% and $90 \%\left(\mathrm{LC}_{50}, \mathrm{LC}_{90}\right)$ and other statistical parameters (95\% confidence limits of upper confidence limit and lower confidence limit values), and chi-square test were calculated using the SPSS (Statistical Package of Social Sciences) software version 13 (IBM Corp., Armonk, NY, USA).

\section{Results}

\section{Larval and pupal toxicity}

Larva and pupal mortality of St. aegypti after treatment with acetone extract of T. patula leaf is shown in Table $1.18 \%$ mortality was noted in
I instar larvae after the treatment with $2 \mathrm{mg} / \mathrm{L}$ concentration whereas it has been increased to $93 \%$ at $10 \mathrm{mg} / \mathrm{L}$ concentration. The observed $\mathrm{LC}_{50}$ values $(5.73 \mathrm{mg} / \mathrm{L}, 6.11 \mathrm{mg} / \mathrm{L}, 6.41 \mathrm{mg} / \mathrm{L}, 6.77 \mathrm{mg} / \mathrm{L}$ and $5.38 \mathrm{mg} / \mathrm{L}$ for $1^{\text {st }}, 2^{\text {nd }}, 3^{\text {rd }}, 4^{\text {th }}$ instar and pupae of $S t$. aegypti respectively) indicates that T. patula is effective over the larvae and pupae of St. aegypti at lower concentration ranging between $5 \mathrm{mg} / \mathrm{L}$ to $7 \mathrm{mg} / \mathrm{L}$. Early instars were susceptible to T. patula when compared with the later ones.

Table 2 provides the larval and pupal mortality of St. aegypti after treatment with methanol extract of $C$. phlomidis flowers at different concentrations (2 mg/L, $4 \mathrm{mg} / \mathrm{L}, 6 \mathrm{mg} / \mathrm{L}, 8 \mathrm{mg} / \mathrm{L}$ and $10 \mathrm{mg} / \mathrm{L}$ ). The lowest mortality rate recorded was $12 \%$ in IV instar after the treatment with $2 \mathrm{mg} / \mathrm{L}$ concentration and the maximum mortality rate recorded was $85 \%$ in I instar after the treatment with $10 \mathrm{mg} / \mathrm{L}$ concentration. The $\mathrm{LC}_{50}$ values of $C$. phlomidis flower extract $(6.05 \mathrm{mg} / \mathrm{L}, 6.41 \mathrm{mg} / \mathrm{L}, 6.85$ $\mathrm{mg} / \mathrm{L}, 7.50 \mathrm{mg} / \mathrm{L}$ and $7.71 \mathrm{mg} / \mathrm{L}$ for I-IV larval instars and pupal stage, respectively) were lower. There was no significant variation in median LC among the various developmental stages.

Larval and pupal mortality of St. aegypti after the treatment of methanol extract of $C$. roseus leaf extract at different concentrations (2 $\mathrm{mg} / \mathrm{L}, 4 \mathrm{mg} / \mathrm{L}, 6 \mathrm{mg} / \mathrm{L}, 8 \mathrm{mg} / \mathrm{L}$ and $10 \mathrm{mg} / \mathrm{L}$ ) is given in Table 3 . A percentage of $89 \%$ mortality was observed in I instar at a treatment of 10 $\mathrm{mg} / \mathrm{L}$ concentration. Significant variation in mortality was observed among the different concentrations tested. The lowest recorded $\mathrm{LC}_{50}$

\begin{tabular}{|c|c|c|c|c|c|c|c|c|c|}
\hline \multirow[t]{2}{*}{$\begin{array}{l}\text { Larval instars } \\
\text { and pupal stage }\end{array}$} & \multicolumn{6}{|c|}{$\begin{array}{c}\text { \% Larval/pupal mortality (mean } \pm \text { SD) } \\
\text { Concentration (mg/L) }\end{array}$} & \multirow[t]{2}{*}{$\begin{array}{c}\mathrm{LC}_{50} \\
(\mathrm{LCL} / \mathrm{UCL})\end{array}$} & \multirow[t]{2}{*}{$\begin{array}{c}\mathrm{LC}_{90} \\
\text { (LCL/UCL) }\end{array}$} & \multirow[t]{2}{*}{$\begin{array}{c}\chi^{2} \\
\text { value }\end{array}$} \\
\hline & Control & 2 & 4 & 6 & 8 & 10 & & & \\
\hline I & $2 \pm 0.4^{\mathrm{a}}$ & $18 \pm 0.94^{b}$ & $36 \pm 1.63^{c}$ & $50 \pm 1.25^{\mathrm{d}}$ & $63 \pm 0.82^{\mathrm{e}}$ & $93 \pm 0.47^{\mathrm{f}}$ & $\begin{array}{c}5.73 \\
(4.27 / 7.17)\end{array}$ & $\begin{array}{c}10.71 \\
(8.77 / 15.77)\end{array}$ & $8.63^{*}$ \\
\hline II & $3 \pm 0.4^{\mathrm{a}}$ & $15 \pm 0.82^{b}$ & $35 \pm 1.63^{c}$ & $45 \pm 0.82^{\mathrm{d}}$ & $60 \pm 1.63^{\mathrm{e}}$ & $90 \pm 0.47^{\mathrm{f}}$ & $\begin{array}{c}6.11 \\
(5.29 / 8.28)\end{array}$ & $\begin{array}{c}11.18 \\
(9.18 / 16.33)\end{array}$ & $8.08^{*}$ \\
\hline III & $2 \pm 0.2^{a}$ & $14 \pm 0.82^{b}$ & $33 \pm 0.47^{c}$ & $41 \pm 1.63^{c d}$ & $58 \pm 0.94^{\mathrm{d}}$ & $87 \pm 0.82^{\mathrm{e}}$ & $\begin{array}{c}6.41 \\
(5.13 / 7.86)\end{array}$ & $\begin{array}{c}11.63 \\
(9.62 / 16.57)\end{array}$ & $6.95^{*}$ \\
\hline IV & $1 \pm 0.1^{\mathrm{a}}$ & $11 \pm 0.82^{b}$ & $30 \pm 1.63^{c}$ & $39 \pm 0.82^{c d}$ & $55 \pm 0.82^{d}$ & $84 \pm 1.63^{e}$ & $\begin{array}{c}6.77 \\
(5.65 / 8.11)\end{array}$ & $\begin{array}{c}11.92 \\
(10.01 / 16.22)\end{array}$ & $5.78^{*}$ \\
\hline Pupae & $1 \pm 0.1^{\mathrm{a}}$ & $31 \pm 2.45^{b}$ & $49 \pm 1.25^{c}$ & $57 \pm 1.63^{\mathrm{d}}$ & $61 \pm 2.05^{\mathrm{e}}$ & $64 \pm 1.25^{\mathrm{e}}$ & $\begin{array}{c}5.38 \\
(4.02 / 6.51)\end{array}$ & $\begin{array}{c}18.19 \\
(14.58 / 26.38)\end{array}$ & $3.75^{*}$ \\
\hline
\end{tabular}

Table 1. Larvicidal and pupicidal activity of Tagetes patula leaf extract on dengue vector Stegomyia aegypti.

a-fMeans \pm standard deviations (SD) followed by same letter within rows indicate no significant difference (Duncan's multiple range test, $\mathrm{P}<0.05$ ). $\mathrm{LC}_{50}$, $\mathrm{LC} 9 \mathrm{~g}_{90}$, lethal concentration at $50 \%$ and $90 \%$; $\mathrm{LCL}$, lower confidence limits; UCL, upper confidence limits. *Significant at $\mathrm{P}<0.001$ (heterogeneity factor used in calculation of confidence limits).

\begin{tabular}{|c|c|c|c|c|c|c|c|c|c|}
\hline \multirow{2}{*}{$\begin{array}{l}\text { Larval instars } \\
\text { and pupal stage }\end{array}$} & \multicolumn{6}{|c|}{$\begin{array}{c}\text { \% Larval/pupal mortality (mean } \pm \text { SD) } \\
\text { Concentration }(\mathrm{mg} / \mathrm{L})\end{array}$} & \multirow[t]{2}{*}{$\begin{array}{c}\mathrm{LC}_{50} \\
(\mathrm{LCL} / \mathrm{UCL})\end{array}$} & \multirow[t]{2}{*}{$\begin{array}{c}\mathrm{LC}_{90} \\
\text { (LCL/UCL) }\end{array}$} & \multirow[t]{2}{*}{$\begin{array}{c}\chi^{2} \\
\text { value }\end{array}$} \\
\hline & Control & 2 & 4 & 6 & 8 & 10 & & & \\
\hline I & $2 \pm 0.5^{\mathrm{a}}$ & $16 \pm 0.82^{b}$ & $33 \pm 0.47^{\mathrm{c}}$ & $49 \pm 1.25^{\mathrm{d}}$ & $65 \pm 2.44^{\mathrm{e}}$ & $85 \pm 1.63^{\mathrm{f}}$ & $\begin{array}{c}6.05 \\
(5.54 / 6.55)\end{array}$ & $\begin{array}{c}11.93 \\
(10.39 / 12.68)\end{array}$ & $0.94 *$ \\
\hline II & $2 \pm 0.5^{a}$ & $15 \pm 1.63^{b}$ & $30 \pm 0.82^{c}$ & $45 \pm 0.82^{d}$ & $61 \pm 2.45^{\mathrm{e}}$ & $83 \pm 0.94^{\mathrm{f}}$ & $\begin{array}{c}6.41 \\
(5.90 / 6.93)\end{array}$ & $\begin{array}{c}11.81 \\
(10.79 / 13.25)\end{array}$ & $1.25^{*}$ \\
\hline III & $1 \pm 0.4^{\mathrm{a}}$ & $13 \pm 1.63^{b}$ & $28 \pm 1.25^{c}$ & $41 \pm 1.25^{\mathrm{d}}$ & $57 \pm 0.82^{\mathrm{e}}$ & $79 \pm 0.94^{\mathrm{f}}$ & $\begin{array}{c}6.85 \\
(5.79 / 8.59)\end{array}$ & $\begin{array}{c}12.43 \\
(9.71 / 16.57)\end{array}$ & $1.19 *$ \\
\hline IV & $1 \pm 0.3^{\mathrm{a}}$ & $12 \pm 2.05^{b}$ & $24 \pm 0.82^{c}$ & $37 \pm 0.47^{\mathrm{d}}$ & $49 \pm 0.94 \mathrm{e}$ & $74 \pm 0.47^{\mathrm{f}}$ & $\begin{array}{c}7.50 \\
(6.94 / 8.17)\end{array}$ & $\begin{array}{c}13.45 \\
(12.13 / 15.40)\end{array}$ & $1.85^{*}$ \\
\hline Pupa & $1 \pm 0.1^{\mathrm{a}}$ & $24 \pm 0.82^{b}$ & $42 \pm 1.25^{c}$ & $45 \pm 2.45^{d}$ & $53 \pm 1.63 \mathrm{e}$ & $55 \pm 0.82^{\mathrm{e}}$ & $\begin{array}{c}7.71 \\
(6.52 / 9.59)\end{array}$ & $\begin{array}{c}21.21 \\
(16.62 / 32.33)\end{array}$ & $3.60^{*}$ \\
\hline
\end{tabular}

Table 2. Larvicidal and pupicidal activity of Clerodendron phlomidis flower extract on dengue vector Stegomyia aegypti.

a-fMeans \pm standard deviations (SD) followed by same letter within rows indicate no significant difference (Duncan's multiple range test, $\mathrm{P}<0.05$ ). $\mathrm{LC}_{50}, \mathrm{LC} 90$, lethal concentration at $50 \%$ and $90 \%$; $\mathrm{LCL}$, lower confidence limits; UCL, upper confidence limits. *Significant at $\mathrm{P}<0.001$ (heterogeneity factor used in calculation of confidence limits). 
was $5.89 \mathrm{mg} / \mathrm{L}$ for the I instar and highest was $6.87 \mathrm{mg} / \mathrm{L}$ for IV instar. The pupae were susceptible $(6.53 \mathrm{mg} / \mathrm{L})$ when compared to the III and IV instar of St. aegypti.

The synergistic effect of $T$. patula leaf extract, $C$. phlomidis flower extract and $C$. roseus leaf extract on the developmental stages of $S t$. aegypti is shown in Table 4. The median LC (1.67 mg/L, $1.97 \mathrm{mg} / \mathrm{L}, 2.25$ $\mathrm{mg} / \mathrm{L}, 2.63 \mathrm{mg} / \mathrm{L}$ and $1.79 \mathrm{mg} / \mathrm{L}$ for the I, II, III, IV larval insatrs and pupa, respectively) were highly reduced when compared with the individual treatment. The maximum mortality of $97 \%$ was observed at $6 \mathrm{mg} / \mathrm{L}$ concentration.

\section{Biological observations}

\section{Adult longevity and fecundity}

The adult life span and number of eggs laid by St. aegypti after the treatment with T. patula leaf extract (TPLE), $C$. phlomidis flower extract (CPFE) and $C$. roseus leaf extract (CRLE) are shown in Table 5. There was significant reduction in adult life span of St. aegypti after the treatment with TPLE, CPFE and CRLE at $4.0 \mathrm{mg} / \mathrm{L}$ and $6 \mathrm{mg} / \mathrm{L}$. The longevity and fecundity effect of individual treatment of TPLE, CPFE and CRLE were relatively close showing no significant difference. Whereas, the combined treatment was much effective than the individual treatment showing significant reduction in longevity and fecundity of St. aegypti.
Egg hatchability, survival rate and adult emergence

Table 6 shows egg hatchability, survival rate and adult emergence of St. aegypti after the treatment of TPLE, CPFE and CRLE in individual and in combination. Egg hatchability was reduced up to $40 \%$ after the treatment with TPLE at $6 \mathrm{mg} / \mathrm{L}$, which was the highest reduction rate in individual treatment. Similarly the survival rate and adult emergence was reduced up to $36 \%$ and $29 \%$, respectively in individual treatment of TPLE at $6 \mathrm{mg} / \mathrm{L}$. Combined treatment of TPLE, CPFE and CRLE was conducted with a very low concentration $(0.5 \mathrm{mg} / \mathrm{L}, 1.0 \mathrm{mg} / \mathrm{L}$ and $1.5 \mathrm{mg} / \mathrm{L})$ where hatchability has been markedly reduced to $15 \%$. The survival rate and adult emergence has been greatly reduced to $10 \%$ and $9 \%$ respectively after the treatment of TPLE, CPFE and CRLE in combination.

\section{Discussion}

Dengue fever is an arboviral disease caused by the DENV serotypes 1-4. It is most prevalent in tropical and subtropical regions around the world, predominantly in urban and semi-urban regions (Muhammad et al., 2015). In tropical and subtropical countries, outbreak of dengue results in thousands of deaths, human suffering and massive economic losses (Epelboin et al., 2013). Since, there are no effective vaccines

Table 3. Larvicidal and pupicidal activity of Catharanthouse roseus leaf extract on dengue vector Stegomyia aegypti.

\begin{tabular}{|c|c|c|c|c|c|c|c|c|c|}
\hline \multirow[t]{2}{*}{$\begin{array}{l}\text { Larval instars } \\
\text { and pupal stage }\end{array}$} & \multicolumn{6}{|c|}{$\begin{array}{c}\% \text { Larval/pupal mortality (mean } \pm \text { SD) } \\
\text { Concentration }(\mathrm{mg} / \mathrm{L})\end{array}$} & \multirow[t]{2}{*}{$\begin{array}{c}\mathrm{LC}_{50} \\
(\mathrm{LCL} / \mathrm{UCL})\end{array}$} & \multirow[t]{2}{*}{$\begin{array}{c}\mathrm{LC}_{90} \\
(\mathrm{LCL} / \mathrm{UCL})\end{array}$} & \multirow[t]{2}{*}{$\begin{array}{c}\chi^{2} \\
\text { value }\end{array}$} \\
\hline & Control & 2 & 4 & 6 & 8 & 10 & & & \\
\hline I & $3 \pm 0.7^{\mathrm{a}}$ & $17 \pm 0.82^{b}$ & $35 \pm 0.82^{c}$ & $49 \pm 1.63^{\mathrm{d}}$ & $64 \pm 0.82^{\mathrm{e}}$ & $89 \pm 0.47^{\mathrm{f}}$ & $\begin{array}{c}5.89 \\
(5.39 / 6.37)\end{array}$ & $\begin{array}{c}11.05 \\
(10.13 / 12.31)\end{array}$ & $3.79 *$ \\
\hline II & $3 \pm 0.5^{\mathrm{a}}$ & $15 \pm 0.82^{b}$ & $34 \pm 1.63^{\mathrm{c}}$ & $48 \pm 0.82^{d}$ & $61 \pm 0.82^{\mathrm{e}}$ & $85 \pm 1.25^{f}$ & $\begin{array}{c}6.18 \\
(5.67 / 6.69)\end{array}$ & $\begin{array}{c}11.58 \\
(10.58 / 12.99)\end{array}$ & $2.92 *$ \\
\hline III & $2 \pm 0.4^{\mathrm{a}}$ & $14 \pm 1.25^{b}$ & $31 \pm 0.82^{c}$ & $44 \pm 0.82^{d}$ & $59 \pm 0.82^{\mathrm{e}}$ & $80 \pm 2.45^{\mathrm{f}}$ & $\begin{array}{c}6.59 \\
(6.06 / 7.14)\end{array}$ & $\begin{array}{c}12.26 \\
(11.15 / 13.86)\end{array}$ & $1.33^{*}$ \\
\hline IV & $2 \pm 0.5^{\mathrm{a}}$ & $14 \pm 1.25^{b}$ & $29 \pm 2.45^{c}$ & $41 \pm 1.63^{d}$ & $55 \pm 0.82^{\mathrm{e}}$ & $79 \pm 0.82^{\mathrm{f}}$ & $\begin{array}{c}6.87 \\
(6.33 / 7.45)\end{array}$ & $\begin{array}{c}12.67 \\
(11.48 / 14.40)\end{array}$ & $2.08^{*}$ \\
\hline Pupa & $1 \pm 0.2^{\mathrm{a}}$ & $22 \pm 1.63^{b}$ & $45 \pm 2.45^{c}$ & $50 \pm 2.45^{\mathrm{cd}}$ & $59 \pm 0.82^{d}$ & $62 \pm 0.82^{\mathrm{e}}$ & $\begin{array}{c}6.53 \\
(3.89 / 10.35)\end{array}$ & $\begin{array}{c}17.00 \\
(12.06 / 49.70)\end{array}$ & $5.83^{*}$ \\
\hline
\end{tabular}

a-Feans \pm standard deviations (SD) followed by same letter within rows indicate no significant difference (Duncan's multiple range test, $\mathrm{P}<0.05$ ). $\mathrm{L} \mathrm{LC}_{50}, \mathrm{~L} \mathrm{~L}_{90}$, lethal concentration at $50 \%$ and $90 \%$; $\mathrm{LCL}$, lower confidence limits; UCL, upper confidence limits. *Significant at $\mathrm{P}<0.001$ (heterogeneity factor used in calculation of confidence limits).

Table 4. Larvicidal and pupicidal activity of a mixture of Tagetes patula leaf extract, Clerodendron phlomidis flower extract, Catharanthouse roseus leaf extract on dengue vector Stegomyia aegypti.

\begin{tabular}{|c|c|c|c|c|c|c|c|c|}
\hline \multirow[t]{2}{*}{$\begin{array}{l}\text { Larval instars } \\
\text { and pupal stage }\end{array}$} & \multicolumn{5}{|c|}{$\begin{array}{l}\text { \% Larval/pupal mortality (mean } \pm \text { SD) } \\
\text { Concentration (mg/L) }\end{array}$} & \multirow[t]{2}{*}{$\begin{array}{c}\mathrm{LC}_{50} \\
(\mathrm{LCL} / \mathrm{UCL})\end{array}$} & \multirow[t]{2}{*}{$\begin{array}{c}\mathrm{LC}_{90} \\
(\mathrm{LCL} / \mathrm{UCL})\end{array}$} & \multirow[t]{2}{*}{$\begin{array}{c}\chi^{2} \\
\text { value }\end{array}$} \\
\hline & Control & 1.5 & 3 & 4.5 & 6 & & & \\
\hline I & $1 \pm 0.1^{\mathrm{a}}$ & $51 \pm 0.47^{b}$ & $66 \pm 1.63^{c}$ & $77 \pm 0.82^{\mathrm{d}}$ & $97 \pm 0.82^{\mathrm{e}}$ & $\begin{array}{c}1.67 \\
(-929.24 / 3.21)\end{array}$ & $\begin{array}{c}5.43 \\
(3.80 / 1272.94)\end{array}$ & $5.80^{*}$ \\
\hline II & $3 \pm 0.8^{a}$ & $47 \pm 1.63^{b}$ & $62 \pm 0.47^{c}$ & $75 \pm 1.63^{\mathrm{d}}$ & $96 \pm 0.47^{\mathrm{e}}$ & $\begin{array}{c}1.97 \\
(-12.56 / 3.38)\end{array}$ & $\begin{array}{c}5.65 \\
(4.08 / 30.13) \\
\end{array}$ & $5.27^{*}$ \\
\hline III & $1 \pm 0.4^{\mathrm{a}}$ & $43 \pm 0.55^{b}$ & $59 \pm 2.45^{c}$ & $71 \pm 1.63^{\mathrm{d}}$ & $93 \pm 2.45^{\mathrm{e}}$ & $\begin{array}{c}2.25 \\
(-3.13 / 3.50)\end{array}$ & $\begin{array}{c}6.14 \\
(4.57 / 17.28)\end{array}$ & $3.95^{*}$ \\
\hline IV & $2 \pm 0.4^{a}$ & $39 \pm 1.70^{b}$ & $53 \pm 0.94^{c}$ & $67 \pm 1.24^{\mathrm{d}}$ & $89 \pm 1.63^{\mathrm{e}}$ & $\begin{array}{c}2.63 \\
(2.06 / 3.06)\end{array}$ & $\begin{array}{c}6.72 \\
(5.95 / 7.95)\end{array}$ & $2.76^{*}$ \\
\hline Pupa & $1 \pm 0.2^{a}$ & $49 \pm 2.45^{c}$ & $65 \pm 1.25^{c}$ & $75 \pm 1.25^{\mathrm{d}}$ & $96 \pm 1.25 \mathrm{e}$ & $\begin{array}{c}1.79 \\
(-55.17 / 3.30)\end{array}$ & $\begin{array}{c}5.64 \\
(3.99 / 92.39)\end{array}$ & $5.51^{*}$ \\
\hline
\end{tabular}

a-e Means \pm standard deviations (SD) followed by same letter within rows indicate no significant difference (Duncan's multiple range test, $\mathrm{P}<0.05$ ). $\mathrm{LC} \mathrm{C}_{50}, \mathrm{LC} 90$, lethal concentration at $50 \%$ and $90 \%$; $\mathrm{LCL}$, lower confidence limits; UCL, upper confidence limits. *Significant at $\mathrm{P}<0.001$ (heterogeneity factor used in calculation of confidence limits). 
Table 5. Effect of Tagete patula leaf extract, Cleridendron phlomidis flower extract and Catharanthus roseus leaf extract on adult longevity and fecundity of Stegomyia aegypti females.

\begin{tabular}{|c|c|c|c|c|}
\hline \multirow[t]{2}{*}{ Treatment (mg/L) } & & \multicolumn{2}{|c|}{ Adult longevity } & \multirow{2}{*}{$\begin{array}{l}\text { Fecundity } \\
\text { (No. of eggs) }\end{array}$} \\
\hline & & Male & Female & \\
\hline & Control & $10 \pm 0.2^{\mathrm{a}}$ & $13.5 \pm 0.2^{\mathrm{a}}$ & $180 \pm 0.4^{\mathrm{a}}$ \\
\hline TPLE (mg/L) & $\begin{array}{l}4.0 \\
6.0\end{array}$ & $\begin{array}{l}7.6 \pm 0.6^{\mathrm{b}} \\
6.2 \pm 0.4^{\mathrm{bc}}\end{array}$ & $\begin{array}{l}8.3 \pm 0.4^{b} \\
6.9 \pm 0.5^{c}\end{array}$ & $\begin{array}{c}94 \pm 1.5^{b} \\
73 \pm 1.1^{\text {bc }}\end{array}$ \\
\hline $\mathrm{CPFE}(\mathrm{mg} / \mathrm{L})$ & 4.0 & $9.0 \pm 0.2^{\mathrm{ab}}$ & $9 \pm 0.2^{b}$ & $97 \pm 1.6^{\mathrm{b}}$ \\
\hline \multirow[t]{2}{*}{ CRLE (mg/L) } & $\begin{array}{l}6.0 \\
4.0 \\
6.0\end{array}$ & $\begin{array}{c}8.0 \pm 0.5^{b} \\
8.5 \pm 0.4^{b} \\
7.8 \pm 0.4^{b c}\end{array}$ & $\begin{array}{l}7 \pm 0.9^{c} \\
9 \pm 1.1^{b} \\
7 \pm 0.9^{c}\end{array}$ & $\begin{array}{c}80 \pm 1.1^{b c} \\
97 \pm 0.9^{b} \\
80 \pm 0.6^{b c}\end{array}$ \\
\hline & Control & $10 \pm 0.2^{\mathrm{a}}$ & $13.5 \pm 0.2^{\mathrm{a}}$ & $180 \pm 0.4^{\mathrm{a}}$ \\
\hline TPLE+CPFE+CRLE (mg/L) & $\begin{array}{c}0.5 \\
1 \\
1.5\end{array}$ & $\begin{array}{l}8 \pm 0.9^{b} \\
6 \pm 0.6^{c} \\
4 \pm 0.9^{d}\end{array}$ & $\begin{array}{l}6 \pm 0.6^{\mathrm{b}} \\
4 \pm 1.5^{\mathrm{c}} \\
3 \pm 0.9^{\mathrm{d}}\end{array}$ & $\begin{array}{l}55 \pm 1.9^{\mathrm{b}} \\
43 \pm 2.1^{\mathrm{c}} \\
25 \pm 1.6^{\mathrm{d}}\end{array}$ \\
\hline
\end{tabular}

a-d Means \pm standard deviations (SD) followed by same letter within column indicate no significant difference (Duncan's multiple range test, P<0.05). TPLE, Tagete patula leaf extract; CPFE, Cleridendron phlomidis flower extract; CRLE, Catharanthus roseus leaf extract.

Table 6. Egg hatchability, survival rate and adult emergency of Stegomyia aegypti after the treatment of Tagete patula leaf extract, Cleridendron phlomidis flower extract and Catharanthus roseus leaf extract.

\begin{tabular}{|c|c|c|c|c|}
\hline Treatment (mg/L) & & Egg hatchability (\%) & Survival (\%) & Adult emergence \\
\hline & Control & $100 \pm 0.5^{\mathrm{a}}$ & $100 \pm 0.4^{\mathrm{a}}$ & $180 \pm 2.4^{\mathrm{a}}$ \\
\hline TPLE (mg/L) & $\begin{array}{l}4.0 \\
6.0\end{array}$ & $\begin{array}{c}54 \pm 1.1^{b} \\
40 \pm 1.1^{b c}\end{array}$ & $\begin{array}{l}49 \pm 0.6^{b} \\
36 \pm 0.8^{c}\end{array}$ & $\begin{array}{l}44 \pm 2.1^{b} \\
29 \pm 2.9^{c}\end{array}$ \\
\hline CPFE (mg/L) & $\begin{array}{l}4.0 \\
6.0\end{array}$ & $\begin{array}{c}64 \pm 0.2^{\mathrm{b}} \\
57 \pm 0.4^{\mathrm{bc}}\end{array}$ & $\begin{array}{c}56 \pm 1.1^{\mathrm{b}} \\
48 \pm 1.6^{\mathrm{bc}}\end{array}$ & $\begin{array}{c}49 \pm 1.1^{b} \\
37 \pm 1.4^{b c}\end{array}$ \\
\hline CRLE (mg/L) & $\begin{array}{l}4.0 \\
6.0\end{array}$ & $\begin{array}{c}55 \pm 0.9^{b} \\
47 \pm 0.2^{b c}\end{array}$ & $\begin{array}{c}50 \pm 0.9^{b} \\
39 \pm 0.6^{b c}\end{array}$ & $\begin{array}{c}43 \pm 1.9^{b} \\
32 \pm 1.1^{b c}\end{array}$ \\
\hline & Control & $100 \pm 0.5^{\mathrm{a}}$ & $100 \pm 0.4^{\mathrm{a}}$ & $180 \pm 2.4^{\mathrm{a}}$ \\
\hline TPLE+CPFE+CRLE (mg/L) & $\begin{array}{l}0.5 \\
1.0 \\
1.5\end{array}$ & $\begin{array}{l}85 \pm 0.1^{\text {b }} \\
34 \pm 0.9^{c} \\
15 \pm 1.6^{\text {d }}\end{array}$ & $\begin{array}{c}31 \pm 0.4^{\mathrm{b}} \\
20 \pm 1.6^{\mathrm{bc}} \\
10 \pm 1.1^{\mathrm{c}}\end{array}$ & $\begin{array}{c}26 \pm 1.5^{b} \\
15 \pm 0.9 \mathrm{bc} \\
9 \pm 2.1^{\mathrm{c}}\end{array}$ \\
\hline
\end{tabular}

a-dMeans \pm standard deviations (SD) followed by same letter within column indicate no significant difference (Duncan's multiple range test, P<0.05). TPLE, Tagete patula leaf extract; CPFE, Cleridendron phlomidis flower extract; CRLE, Catharanthus roseus leaf extract.

available for dengue virus so that its control solely depends on effective vector control measures (Suresh et al., 2015).

Dengue virus is primarily transmitted by Aedes mosquitoes, particularly A. aegypti, which is frequently dependent on applications of conventional synthetic insecticides which are toxic to human and other non-target organisms (Remia \& Logaswamy, 2010; Tabanca et al., 2013). A good control measure lies on personal protection, public awareness for removal of mosquito breeding sites and controlling mosquito immatures through environment friendly and target specific larvicides (Ghosh et al., 2012; Poopathi, 2012; Govindarajan \& Sivakumar, 2014; Patil et al., 2014).

In present study, as an alternative to synthetic pesticides, three plant extracts (T. patula, C. phlomidis and $C$. roseus) have been tested against St. aegypti. Recent research works show that the active metabolites present in different parts of plants exhibit a wide range of toxicity against various mosquito species. Dass \& Mariappan (2014) reported the larvicidal effect of the extract of Lawsonia inermis and Murraya exotica leaves on III and IV larval instars and pupa of Culex quinquefasciatus. Shivakumar et al. (2013) reported the larvicidal potential of leaf extracts of five plants (Blepharis maderaspatensis, Elaeagnus indica, Maesa indica, Phyllanthus wightianus and Memecylon edule) extracted with different solvent crude (hexane, chloroform, ethyl acetate, ace- tone and methanol) against the fourth-instar larvae of Aedes aegypti.

Tagetes patula extract have exhibited an increased toxicity on different larval instars and pupae of St. aegypti when compared with the extracts of $C$. phlomidis and $C$. roseus. The mosquitocidal activity of the test plants are due to the presence of active secondary metabolite such as phenols, flavonoide, alkaloids, saponins, and terpenes in T. patula (Ramya et al., 2012); pectolinaringenin, scutellarein, clerodin, clerodendrin, etc. in Clerodendron phlomidis (Mohan \& Mishra, 2010); Catharanthine, serpentine, tabersonine, vindoline, vinblastine, vincristine, ajmalicine, tryptophan, tryptamine and secologanine in Catharanthus roseus (Tikhomiroff \& Jolicoeur, 2002).

In this study the synergistic activity of T. patula, C. phlomidis and $C$. roseus combination was evaluated on the larval instars and puape of $S t$. aegypti and revealed that the combined treatment is much effective than the individual treatment. Recent research has showed that the synergistic activities of the secondary metabolites of plants are much toxic against mosquitoes and other insect vectors. For instance, Yankanchi et al. (2014) reported that maximum synergistic activities were found in combining extracts of $V$. negundo and P. glabra. The combined effects of cypermethrin and extracts of Calotropis procera root, Piper longum root and Polygonum hydropiper leaves were most effective against the housefly, Musca domestica (Islam \& Aktar, 2013). 
The active compounds of $T$. patula, $C$. phlomidis and $C$. roseus were also responsible for the reduction in duration of St. aegypti life cycle and inhibition of adult emergence. Kumar \& Chapman (1984) observed reduction in adult longevity of $P$. xylostella when larval stages were treated with permethrin and fenvalerate. Similar response were also observed for Culex pipiens and Culesita longiareolata treated with Bacillus thuringiensis (Aissaoui \& Boudjelida, 2014) and A. aegypti and C. quinquefasciatus treated with Bacillus sphaericus (Nareshkumar et al., 2012). The adult which emerged from treated larvae and pupae showed a great reduction in fecundity. The numbers of eggs laid were reduced to around $50 \%$ in individual treatment of the test plants whereas; it has been reduced to $13 \%$ in the combined treatment. This may be due to the synergistic behaviours of active ingredients present in the plant materials. Senthil Nathan et al. (2004) reported the synergistic activity of Bacillus thuringiensis with neem and pongamia resulting in reduction of fecundity in rice leaffolder, Cnaphalocrocis medinalis.

The study shows that the active ingredients influenced the egg hatchability. Results showed that $T$. patula leaf extract, $C$. phlomides flower extract, and $C$. roseus leaf extract inhibited egg hatching from $40-50 \%$ whereas the combined treatment inhibited around $85 \%$. The adult emergence and survival of larvae from the eggs of treated larvae were also greatly reduced when compared with control. Insects with abnormal behaviours such as slow movement and loss of equilibrium were also observed during the study. Rajkumar et al. (2011) reported reduced egg hatchability in malarial mosquito, Anopheles stephensi treated with leaf essential oil of Coccinia indica.

\section{Conclusions}

From the present study we conclude that the T. patula leaf extracts, $C$. phlomides flower extract, and $C$. roseus leaf extract can be used as an effective mosquito control agent. The three plant extracts can be used in combination to target mosquitoes at very low concentration. Additional research is needed to produce target specific bio-pesticides by screening the active compounds that actually cause impairment and death to mosquitoes. This may increase the biological activity of the product against mosquito larvae to levels proportionate with commercially available pesticides.

\section{References}

ABBOTT W.S.B., 1925 - A method of computing the effectiveness of insecticides. - J. Econ. Entomol. 18: 267-269.

AHMAD M., 2007 - Insecticide resistance mechanisms and their management in Helicoverpa armigera (Hubner) - A review. - J. Agric. Res. 45: 319-335.

AISSAOUI A., BOUDJELIDA H., 2014 - Larvicidal activity and influence of Bacillus thuringiensis (Vectobac G), on longevity and fecundity of mosquito species. - Eur. J. Exp. Bio. 4: 104-109.

ALDER H.L., ROSSLER E.B.F., 1977 - Introduction to probability and statistics. - Wiley \& Sons, San Francisco: 246.

AMERASAN D., MURUGAN K., PANNEERSELVAM C., KANAGARAJU N., KOVENDAN K., MAHESH KUMAR P., 2015 - Bioefficacy of Morinda tinctoria and Pongamia glabra plant extracts against the malaria vector Anopheles stephensi (Diptera: Culicidae). - J. Entomol. Acarol. Res. 47: 1986.

BRATHWAITE DICK 0., SAN MARTÍN J.L., MONTOYA R.H., DEL DIEG0 J., ZAMBRANO B., DAYAN G.H., 2012 - The history of dengue outbreaks in the Americas. - Am. J. Trop. Med. Hyg. 87: 584-93.

CAMARILLO G., ORTEGA L., SERRATO M., RODRÍGUEZ-HERNÁNDEZ
C., 2007 - Capitulo 5: Tagetes spp. plantas con potencial en el control de plagas. - Agric. Sostenible. 3: 32-39.

CANTRELL C.L., DAYAN F.E., DUKE S.0., 2012 - Natural products as sources for new pesticides. - J. Nat. Prod. 75: 1231-1242.

DASS K., MARIAPPAN P., 2014 - Larvicidal activity of Lawsonia inermis and Murraya exotica leaves extract on filarial vector, Culex quinquefasciatus. - Int. J. Mosq. Res. 1: 25-27.

DE LA MORA-COVARRUBIAS A., JIMÉNEZ-VEGA F., TREVIÑO-AGUILAR S.M., 2010 - Geospatial distribution and detection of dengue virus in mosquitoes Aedes (Stegomyia) aegypti in Ciudad Juarez, Chihuahua, Mexico. - Salud. Publica. Mex. 52: 127-33.

EPELBOIN L., BOULLE C., OUAR-EPELBOIN S., HANF M., DUSSART P., DJOSSOU F., NACHER M., CARME B., 2013 - Discriminating malaria from dengue fever in endemic areas: clinical and biological criteria, prognostic score and utility of the C-reactive protein: a retrospective matched-pair study in French Guiana. - PLoS Negl. Trop. Dis. 7: e2420.

FINNEY D.J., 1971 - Probit analysis. - Cambridge University Press, London: 68-78.

FONSECA-GONZÁLEZ I., QUIÑONES M.L., LENHART A., BROGDON W.G., 2011 - Insecticide resistance status of Aedes aegypti (L.) from Colombia. - Pest. Manag. Sci. 67: 430-7.

GHOSH A., CHOWDHURY N., CHANDRA G., 2012 - Plant extracts as potential mosquito larvicides. - Indian J.Med. Res. 135: 581-598.

GOVINDARAJAN M., SIVAKUMAR R., 2014 - Larvicidal, ovicidal, and adulticidal efficacy of Erythrina indica (Lam.) (Family: Fabaceae) against Anopheles stephensi, Aedes aegypti, and Culex quinquefasciatus (Diptera: Culicidae). - Parasitol. Res. 113: 777- 791.

GUZMAN M.G., HALSTEAD S.B., ARTSOB H., BUCHY P., FARRAR J., GUBLER DJ., HUNSPERGER E., KROEGER A., MARGOLIS HS., MARTÍNEZ E., NATHAN MB., PELEGRINO JL., SIMMONS C., YOKSAN S., PEELING RW., 2010 - Dengue: a continuing global threat. Nat. Rev. Microbiol. 8: S7-16.

ISLAM M.S., AKTAR M.J., 2013 - Larvicidal efficacies of some plant extracts and their synergistic effects with cypermethrin on the lifehistory traits of Musca Domestica L. - Int. J. Innov. Biosci. 3: 92-103.

JALEEL C.A., GOPI R., MANIVANNAN P., SANKAR B., 2007 - Induction of drought strees tolerance by ketoconazole in Catharanthus roseus is mediated by enhanced antioxidant potentials and secondary metabolite accumulation. - Colloids Surf. B. Biointerfaces. 60: 202-206.

JAYAPRIYA G., GRICILDA S.F., 2015 - Bioefficacy of leaf extracts of Rhinacanthus Nasutus Linn (Acanthaceae) against Aedes Aegypti Linn and Culex Quinquefasciatus Say. - IJPRBS. 4: 219-233.

KASHIF M., BANO S., NAQVI S., FAIZI S., LUBNA., AHMED MESAIK M., AZEEMI K.S., FAR00Q A.D., 2015 - Cytotoxic and antioxidant properties of phenolic compounds from Tagetes patula flower. - Pharm. Biol. 53: 5 .

KASHTE S., WALKE S., PARWE N., MULANI R., 2015 - Agnimantha: an herbal larvicide and pupicide against malarial vector Anopheles stephensi. - Int. J. Mosq. Res. 2: 89-93.

KHAN H.A., AKRAM W., SHEHZAD K., SHAALAN E.A., 2011 - First report of field evolved resistance to agrochemicals in dengue mosquito, Aedes albopictus (Diptera: Culicidae), from Pakistan. - Parasit. Vectors. 4: 146.

KUMAR K., CHAPMAN R.B., 1984 - Sublethal effects of insecticides on the diamondback moth Plutella xylostella (L.). - Pestic. Sci. 15: 344-352.

LAKSHMI V., VIJI STELLA BAI G., 2015 - Antidiabetic activity of Clerodendrum phlomidis l. against streptozotocin (stz) induced diabetics in rats. - Int. J. Res. Biol. Sci. 5: 7-11.

MARQUES A.M., KAPLAN M.A.C., 2015 - Active metabolites of the genus Piper against Aedes aegypti: natural alternative sources for dengue vector control. - Univ. Sci. 20: 61-82.

MOHAN M.K., MISHRA S.H., 2010 - Comprehensive review of cleroden- 
drum phlomidis: a traditionally used bitter. - J. Chin. Integr. Med. 8: 510-524.

MIRESMAILLI S., ISMAN M.B., 2014 - Botanical insecticides inspired by plant-herbivore chemical interactions. - Trends. Plant. Sci. 19: 29-35.

MUHAMMAD I.Q., KHIZAR A., MADEHA T., MUHAMMAD I., SYEDA F.R.B., BILAL A., MUHAMMAD H., AKHTAR R., MUHAMMAD A., 2015 - Dengue fever: natural management. - Pak. J. Pharm. Sci. 28: 647-655.

MUNHOZ V.M., LONGHINI R., SOUZA J.R.P., ZEQUI J.A.C., LEITE MELLO E.V.S., LOPES G.C., MELLO J.C.P., 2014 - Extraction of flavonoids from Tagetes patula: process optimization and screening for biological activity. - Rev. Bras. Farmacogn. 24: 576-583.

NEJAT N., ALIREZA V., DAVID C., YEE-HOW T., MAHMOOD M., RAMBOD A., 2015 - Ornamental exterior versus therapeutic interior of Madagascar Periwinkle (Catharanthus roseus): the two faces of a versatile herb. - Sci. World J. 2015: 982412.

NARESHKUMAR A., JEYALALITHA T., MURUGAN K., MADHIYAZHAGAN P., 2013 - Bioefficacy of plant-mediated gold nanoparticles and Anthocepholus cadamba on filarial vector, Culex quinquefasciatus (Insecta: Diptera: Culicidae). - Parasitol. Res. 112: 1053-1063.

NARESHKUMAR A., MURUGAN K., BARUAH I., MADHIYAZHAGAN P., NATARAJ T., 2012 - Larvicidal potentiality, longevity and fecundity inhibitory activities of Bacillus sphaericus (Bs G3-IV) on vector mosquitoes, Aedes aegypti and Culex quinquefasciatus. - J. Entomol. Acarol. Res. 44: e15.

NARESHKUMAR A., MURUGAN K., THOMAS VINCENT C., MADHIYAZHAGAN P., NATARAJ T., SHOBANA K., 2015 - The distribution of Culex mosquitoes in Coimbatore, Tamil Nadu, India. - J. Entomol. Acarol. Res. 47: 4565.

PANNEERSELVAM C., MURUGAN K., KOVENDAN K., MAHESHKUMAR P., PONARULSELVAM S., AMERASAN D., SUBRAMANIAM J., HWANG J.S., 2013 - Larvicidal efficacy of Catharanthus roseus Linn. (Family: Apocynaceae) leaf extract and bacterial insecticide Bacillus thuringiensis against Anopheles stephensi Liston. - Asian Pac. J. Trop. Med. 847-853.

PATIL P.B., KALLAPUR S.V., KALLAPUR V.L., HOLIHOSUR S.N., 2014 Clerodendron inerme Gaertn. Plant as an effective natural product against dengue and filarial vector mosquitoes. - Asian Pac. J. Trop. Dis. 4: S453-S462.

PRAKASH 0., ROUT P.K., CHANOTIYA C.S., MISRA L.N., 2012 Composition of essential oil, concrete, absolute and SPME analysis of Tagetes patula capitula. - Ind. Crops. Prod. 37: 195-199.

P00PATHI S., 2012 - Current trends in the control of mosquito vectors by means of biological larvicides. - J. Biofertil. Biopestic. 3: 2-14.

RAJASEKARAN A., DURAIKANNAN G., 2012 - Larvicidal activity of plants extracts an Aedes aegypti. - Asian Pac. J. Trop. Biomed. 2: S1578-S1582.

RAJKUMAR S., JEBANESAN A., NAGARAJAN R., 2011 - Effect of leaf essential oil of Coccinia indica on egg hatchability and different larval instars of malarial mosquito Anopheles stephensi. Asian Pac. J. Trop. Med. 2: 948-951.

RAMYA R., MAHNA S., BHANUMATHI., SAMANTA P., BHAT S.K., 2012 Analysis of photochemical composition and bacteriostatic activity of Tagetes sp. - Int. Res. J. Pharmacy. $3: 114-115$.

REEGAN A.D., GANDHI M.R., PAULRAJ M.G., IGNACIMUTHU S., 2014 Larvicidal activity of medicinal plant extracts against Culex quinquefasciatus Say and Aedes aegypti mosquitoes (Diptera: Culicidae). - Int. J. Pure. Appl. Zool. 2: 205-210.
REMIA K.M., LOGASWAMY S., 2010 - Larvicidal efficacy of leaf extract of two botanicals against the mosquito vector, Aedes aegypti (Diptera: Culicidae). - Indian J. Nat. Prod. Resour. 1: 208-212.

RUIZ-GUERRERO R., RODRÍGUEZ-PÉREZ M.A., NORZAGARAY-CAMPOS M., 2015 - Toxicity of Mexican native plant extracts against larvae of Aedes aegypti (Diptera: Culicidae). - Asian Pac. J. Trop. Biomed. 5: 287-291.

SENTHIL NATHAN S., CHUNG P.G., MURUGAN K., 2004 - Effect of botanical insecticides and bacterial toxins on the gut enzyme of the rice leaf folder Cnaphalocrocis medinalis. - Phytoparasitica. 32: 433-443.

SHIVAKUMAR M. S., SRINIVASAN R., NATARAJAN D., 2013 - Larvicidal potential of some Indian medicinal plant extracts against Aedes aegypti (L.). - Asian J. Pharm. Clin. Res. 6: 77-80.

SIVAPRIYAJOTHI S., MAHESH KUMAR P., KOVENDAN K., SUBRAMANIAM J., MURUGAN K., 2014 - Larvicidal and pupicidal activity of synthesized silver nanoparticles using Leucas aspera leaf extract against mosquito vectors, Aedes aegypti and Anopheles stephensi. J. Entomol. Acarol. Res. 46: 1787.

SURESH U., MURUGAN K., BENELLI G., NICOLETTI M., BARNARD D.R., PANNEERSELVAM C., MAHESH KUMAR P., SUBRAMANIAM J., DINESH D., CHANDRAMOHAN B., 2015 - Tackling the growing threat of dengue: Phyllanthus niruri-mediated synthesis of silver nanoparticles and their mosquitocidal properties against the dengue vector Aedes aegypti (Diptera: Culicidae). - Parasitol. Res. 114: 1551-1562.

TABANCA N., ALI A., BERNIER U.R., KHAN I.A., KOCYIGIT- KAYMAKCIOGLU B., ORUC-EMRE E.E., UNSALAN S., ROLLAS S., 2013 Biting deterrence and insecticidal activity of hydrazide-hydrazones and their corresponding 3-acetyl-2,5-disubstituted-2,3-dihydro-1,3,4oxadiazoles against Aedes aegypti. - Pest Manag. Sci. 69: 703-708.

TIKHOMIROFF C., JOLICOEUR M., 2002 - Screening of Catharanthus roseus secondary metabolites by high-performance liquid chromatography. - J. Chromatogr. A. 955: 87-93.

VADEYAR K.L., HOOLI A.A., HOLIHOSUR S.N., KALLAPUR S.V., 2010 Bioefficacy of Vinca rosea leaf powder on Aedes aegypti. - J. Biopest. 3: 189-191.

VANESSA M., MUNHOZ., RENATA LONGHINI., JOSÉ R.P., SOUZA JOAO A.C., ZEQUI., ENERI V.S., LEITE MELLO., GISELY C., LOPES JOAO C.P., MELLO., 2015 - Extraction of flavonoids from Tagetes patula: processoptimization and screening for biological activity. - Rev. Bras. Farmacogn. 24: 576-583.

VOGEL A.I., 1978 - Text book of practical organic chemistry. - The English Language Book Society and Longman, London: 1368.

VONTAS J., KIOULOS E., PAVLIDI N., MOROU E., DELLA TORRE A., RANSON H., 2012 - Insecticide resistance in the major dengue vectors Aedes albopictus and Aedes aegypti. - Pestic. Biochem. Phys. 104: 126-131.

WORLD HEALTH ORGANIZATION, 2009 - Dengue: guidelines for diagnosis, treatment, prevention and control. Geneva: World Health Organization; 2009. Available from: http://www.who.int/csr/ resources/publications/dengue_9789241547871/en

YANKANCHI S.K., YADAV O.V., JADHAV G.S., 2014 - Synergistic and individual efficacy of certain plant extracts against dengue vector mosquito, Aedes aegypti. - J. Biopest. 7: 22-28. 